\title{
Study on waxing of cut foliage post harvest life of few ornamental species
}

\author{
Vivek Powar $^{1 *}$, Bhavya Bhargava ${ }^{2}$ and Ghumare Vikas ${ }^{3}$ \\ ${ }^{1}$ ASPEE Cllege of Horticulture and Forestry, Navsari Agricultural University, Navsari- 396450 (Gujarat), INDIA \\ ${ }^{2}$ Department of Floriculture and Landscape Architecture, Veer Chandra Singh Garhwali College of Horticulture, \\ Uttarakhand University of Horticulture and Forestry, Bharsar, Pauri Garhwal-246123 (Uttarakhand), INDIA \\ ${ }^{3}$ Agricultural and Food Engineering Department, Indian Institute of Technology, Kharagpur-721302 (West Bengal), \\ INDIA \\ *Corresponding author. E-mail: agrihortiscience@ gmail.com
}

Received: July 22, 2014; Revised received: September 02, 2014; Accepted: November 09, 2014

\begin{abstract}
Enhancing the vase life of cut foliages is one of the prime goals of floriculturist and it is very interesting and important aspect of floriculture. The efforts were made to find out best waxing treatment for enhancing the vase life along with excellent quality maintenance for few cut foliage species. The objective was to evaluate optimum percent wax solution for improving post harvest life and quality of ornamental plants. Different wax emulsion treatments $(0.25,0.50,0.75$ and $1.00 \%)$ showed significant results in both quantitative and qualitative attributes of ornamental species. In Asparagus densiflorus 'Sprengeri' and Eucalyptus teritecornis, $0.75 \%$ wax emulsion concentration recorded minimum foliage weight $(5.62,20.49 \mathrm{~g})$ and minimum water uptake $(5.60,32.73 \mathrm{ml})$ respectively on $3^{\text {rd }}$ day, while maximum foliage weight $(0.90,6.84 \mathrm{~g})$ and maximum water uptake $(1.13,13.77 \mathrm{ml})$ was recorded on senescence day. In Caryota urens (Fishtail palm) $0.50 \%$ wax emulsion concentration recorded minimum foliage weight $(9.71 \mathrm{~g})$, minimum water uptake $(6.53 \mathrm{ml})$ on $3^{\text {rd }}$ day, while maximum foliage weight $(1.83 \mathrm{~g})$ and maximum water uptake $(1.20 \mathrm{ml})$ on senescence day. In Heliconia psittachroum cv. Golden Torch, $1.00 \%$ wax emulsion concentration recorded minimum foliage weight $(28.85 \mathrm{~g})$, minimum water uptake $(20.35 \mathrm{ml})$ on $3^{\text {rd }}$ day, whereas maximum foliage weight $(15.83 \mathrm{~g})$ and maximum water uptake $(5.75 \mathrm{ml})$ on senescence day. There was improvement and increament in post harvest quality and vase life of studied ornamental cut foliages.
\end{abstract}

Keywords: Cut foliage, Emulsion, Post harvest, Vase life, Wax

\section{INTRODUCTION}

Cut greens are important components of floriculture industry and largely used for decoration as filler in floral compositions (Bhattacharjee, 1999). They provide freshness and colour to arrangements and bouquets. The American market wholesale price for foliage plants increased from $\$ 13$ million in 1949 to $\$ 574$ million in 2000 (USDA, 2001). Among them Asparagus densiflours 'Sprengeri', Caryotaurens, Eucalyptus teritecornis and Heliconiapsttachroum cv. Golden Torch are in great demand in European market (CPIDC, 2009). Customers prefers foliage which is attractive in form, colour and freshness of leaves, substantive in texture with all furnished sprays, resistant to wilting and long lasting in flower arrangement, delightful floral designs, bouquets and wreaths. There is an increasing demand for fresh foliage in flower market. Presently, the greens are cut from the wild or from the plants grown for other purposes. Thus post-harvest management of this cut foliage has been indispensable in recent years because of their important role in the international flower market (Bhattacharjee, 1999). The vase life of cut foliage varies with seasons and shorter in the summer ISSN : 0974-9411 (Print), 2231-5209 (Online) All Rights Reserved ๑ Applied and Natural Science Foundation www.ansfoundation.org
(Ferrante et al., 2000). Some species have been shown to benefit from treatments with chemical preservatives (Halevy, 1995).Very meagre research work has been done on vase life of cut foliage in India. Therefore, there is need to study post harvest physiology of these cut foliages. In this context, different wax treatments were studied on cut foliage species to see their effect on quantitative and qualitative attributes.

\section{MATERIALS AND METHODS}

The experiment was carried at the Laboratory of Department of Floriculture and Landscaping, ASPEE College of Horticulture and Forestry Navsari Agricultural University, Navsari. Navsari is situated on the coast of the Arabian Sea at $75^{\circ} 95^{\prime}$ East longitudes, $20^{\circ} 95^{\prime}$ North latitude with an altitude of 10 -12 meters above mean sea level. The climate of this area i.e. south Gujarat is typically tropical, characterized by fairly hot and humid summer, warm and humid monsoon and moderately cold winter.

For experiment purpose, the cut foliages of different ornamentals viz. Asparagus (A. densiflorus 'Sprengeri'), Fishtail palm (Caryotaurens), Eucalyptus (E. teritecornis) and Heliconia (H. psittachroumcv. 
Golden Torch) were harvested early in the morning. These were transferred immediately to a bucket containing freshly collected tap water and taken to laboratory. Foliages were cut uniformly with varying size according to different species and weighed. In waxing treatment, wax emulsion of $0.25 \%, 0.50 \%$, $0.75 \%$ and $1 \%$ was brought from M/s. Navdip Industries, Ahmadabad, Gujarat, India in readymade form. Preparation of solutions was made according to the instructions given on the label of the commercial products and published recommendations, using distilled water. Vase solutions introduced by Halevy et al., (1978) were selected as vase solutions and tap water was the control. The $500 \mathrm{~mL}$ solution of each was used for dipping foliages under each treatment. Subsequently the foliages were dried in air for 5 minutes and then kept in distilled water to check vase life. Cut foliages were removed from the solution after 3 days interval and weighed and gain weight was measured in gram by subtracting the initial weight from final weight (Nowak and Rudnicki, 1990). Equal amount of solution $(800 \mathrm{~mL})$ was kept in each plastic bottle for Heliconia and Eucalyptus while in case of Asparagus and Fishtail Palm equal amount of solution (200 mL) was kept in each conical flask at the time of keeping cut foliages and the volume of solution uptake was measured after every 3 days during the vase life. The remaining solution was measured in $\mathrm{mL}$. The formula to calculate the solution uptake is described by Nowak and Rudnicki (1990).

Uptake of solution $(\mathrm{ml})=$ Initial solution $(\mathrm{ml})-$ Remaining solution (ml).

The data recorded during the experiment were subjected to statistical analysis. The design of analysis used was completely randomized design and analyzed on SPSS 17.0.

\section{RESULTS AND DISCUSSION}

This is well known fact that weight loss and water uptake depends on respiration and transpiration. Due to wax coating on leaves both processes are slowed down. In our experiment, different wax emulsion concentrations had an effect on the weight, water uptake and vase life (Tables 1 and 2) of all species of cut foliages. Fresh weight of cut foliages at $3^{\text {rd }}$ day was influenced by the different stages, while, on $6^{\text {th }}, 9^{\text {th }}$, $12^{\text {th }}$ and senescence day weight and water uptake was decreased.

In Asparagus densiflorus 'Sprengeri', the minimum increase in weight $(5.62 \mathrm{~g})$ and water uptake $(5.60 \mathrm{~mL})$ was observed with $0.75 \%$ wax emulsion treatment i.e. W2 (Tables 1 and 2) on 3rd day. On 6th, 9th and 12th day, same trend was observed by decrease in weight and water uptake in foliages. In which wax emulsion concentration i.e. W2 treatment recorded minimum decrease in weight (4.82 and $2.46 \mathrm{~g}$ ) and water uptake (4.87 and $2.38 \mathrm{~mL}$ ) on respective days and foliages completed their vase life on 12th day whereas the foliages kept in treatments W1, W3, W4 and W5 had completed their vase life before ninth day. Data presented in Table 3 also revealed that among different wax emulsion treatments longer useful vase life (7.00 days) and total vase life (9.00 days) were obtained in treatment W2. In similar findings by Mujaffar and Sankat (2003) observed improvement in shelf life of cut Anthurium cv. Trininad Pink through application of fruit wax. They found that Waxed flowers held under ambient conditions maintained high moisture contents for 15 days, beyond which the moisture content rapidly declined which was due to wax coating being as barrier to loss of moisture. Jaysinghe and Peiris (2009) reported that the longest vase life of 18 days was recorded in treatment 01 , which consisted of pure wax (100\%) in Phoenix roebelenii. According to them the wax solution acts as barrier for dehydration, which also supports to our study.

In Heliconia psittachroum cv. Golden Torch, the minimum increase in weight and water uptake was observed with $1 \%$ wax emulsion treatment i.e. $\mathrm{W}_{1}$ (Table 1). On third, sixth, ninth and twelfth day, the minimum increase in weight of cut foliages $(28.56,26.79,19.96$ and $17.91 \mathrm{~g})$ and minimum water uptake $(20.35,17.18$, 8.63 and $6.88 \mathrm{~mL}$ ) was recorded with treatment $\mathrm{W}_{1}$ respectively as compared to control. The observational data on useful and total vase life of foliages as affected by wax emulsion treatment have been clearly implicated in Table 3, showed significant influence of $1 \%$ (i.e. 9.85 and 11.78 days) wax emulsion treatment on vase life of Heliconia's foliage. It was clearly understood that when the foliages were treated with wax, the turgidity and freshness was maintained because the wax helps in reducing the transpiration and respiration rate (Pritchard et al., 1991). The results obtained are similar to the findings of Paul and Goo (1985) who observed that waxing the Anthurium flowers with carnauba wax reduced water loss and increased vase life The entire shoot system of an herbaceous plant is covered by a cuticle that shows water loss from all its parts including leaves, stems, flowers, fruits and seeds (Cutler et al., 1980; Narayana et al., 1996).

In Caryota urens (Fishtail palm), the minimum increase in weight and water uptake was observed with $0.50 \%$ wax emulsion treatment i.e. $\mathrm{W}_{3}$ (Table 1 ). On third, sixth, ninth and twelfth day, the minimum increase in weight of cut foliages $(9.71,7.95,3.79$ and $2.92 \mathrm{~g})$ and minimum water uptake $(6.53,4.70,2.75$ and $2.35 \mathrm{~mL}$ ) was recorded with treatment $\mathrm{W}_{3}$ respectively as compared to control. The observational data on useful and total vase life of foliages as affected by wax emulsion treatments have been clearly demonstrated in Table 3 and displayed significant influence of $0.50 \%$ (i.e. 10.79 and 10.00 days) wax emulsion treatment on vase life of Fishtail palm's foliage. The present findings were supported by Welch and Cameron (1990) who stated that waxing of canes 


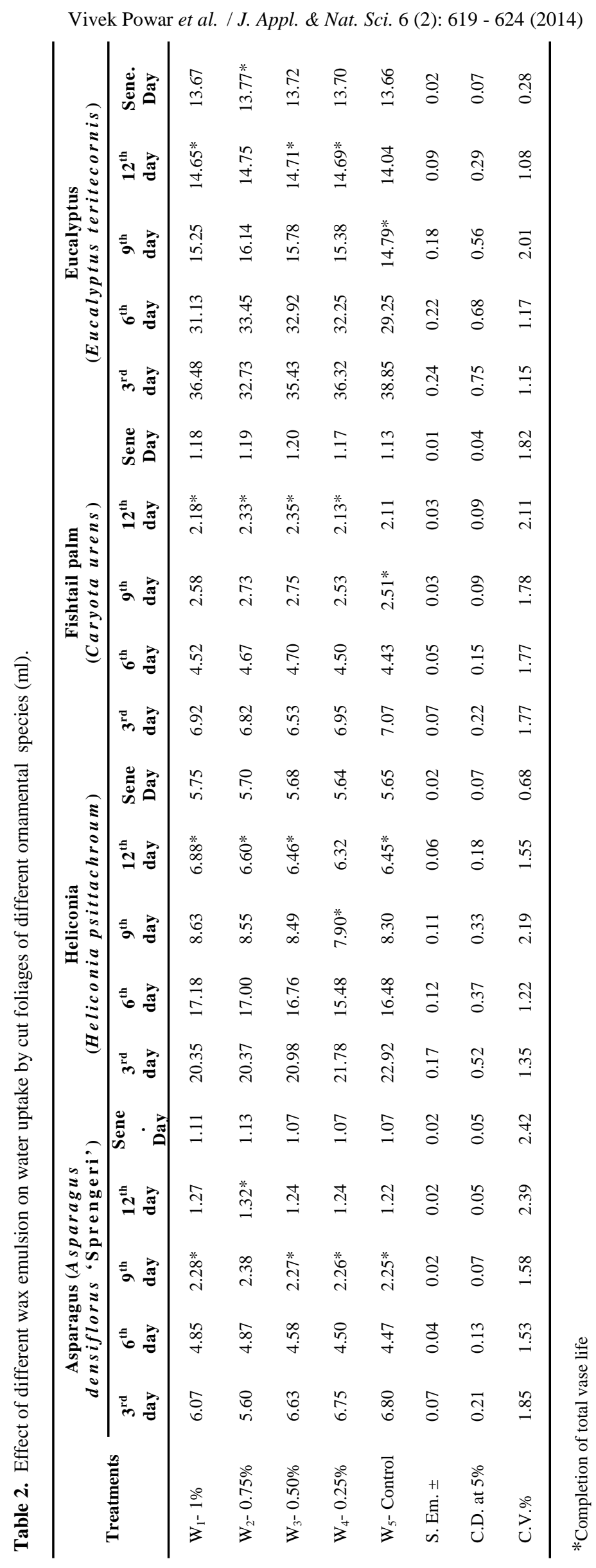


Table 3. Effect of different wax emulsion on vase life of cut foliages of different ornamental species (days).

\begin{tabular}{|c|c|c|c|c|c|c|c|c|}
\hline \multirow[t]{2}{*}{ Treatments } & \multicolumn{2}{|c|}{$\begin{array}{c}\text { Asparagus } \\
\text { (Asparagus densiflorus } \\
\text { 'Sprengeri') }\end{array}$} & \multicolumn{2}{|c|}{$\begin{array}{c}\text { Heliconia } \\
\text { (Heliconia psittachroum) }\end{array}$} & \multicolumn{2}{|c|}{$\begin{array}{l}\text { Fishtail palm } \\
\text { (Caryota urens) }\end{array}$} & \multicolumn{2}{|c|}{$\begin{array}{c}\text { Eucalyptus } \\
\text { (Eucalyptus teritecornis) }\end{array}$} \\
\hline & Useful & Total & Useful & Total & Useful & Total & Useful & Total \\
\hline $\mathrm{W}_{1-}-1 \%$ & 6.00 & 7.77 & 9.85 & 11.78 & 8.00 & 9.80 & 8.00 & 9.00 \\
\hline $\mathrm{W}_{2}-0.75 \%$ & 7.00 & 9.00 & 9.00 & 11.00 & 8.80 & 10.00 & 11.00 & 12.00 \\
\hline $\mathrm{W}_{3}-0.50 \%$ & 5.00 & 6.00 & 8.77 & 10.73 & 9.00 & 10.79 & 10.00 & 11.00 \\
\hline $\mathrm{W}_{4^{-}}-0.25 \%$ & 4.00 & 5.00 & 7.00 & 9.00 & 7.82 & 9.00 & 9.00 & 10.68 \\
\hline $\mathrm{W}_{5^{-}}$Control & 6.80 & 8.00 & 8.00 & 10.00 & 5.00 & 6.84 & 7.80 & 8.00 \\
\hline S. Em. \pm & 0.05 & 0.06 & 0.07 & 0.09 & 0.07 & 0.09 & 0.09 & 0.08 \\
\hline C.D. at $5 \%$ & 0.15 & 0.19 & 0.21 & 0.29 & 0.23 & 0.29 & 0.28 & 0.24 \\
\hline C.V.\% & 1.42 & 1.44 & 1.33 & 1.52 & 1.65 & 1.72 & 1.69 & 1.30 \\
\hline
\end{tabular}

before treatment reduces reduced water loss during stimulated marketing and increased lateral breaks, total season cane growth and in some cases flower production in Rose cv. Show Biz, Tropicana, Hotel Hershey and Femme.

The minimum increase in weight $(20.49,19.27,9.78$, 9.70 and $6.84 \mathrm{~g})$ and water uptake $(32.73,33.45,16.14$, 14.75 and $13.77 \mathrm{~mL}$ ) was observed in $0.75 \%$ wax emulsion treatment on $3^{\text {rd }}, 6^{\text {th }}, 9^{\text {th }}, 12^{\text {th }}$ and senescence day (Table 1 and 2) in Eucalyptus teritecornis. The loss of weight in cut foliages was obtained through transpiration and respiration which can be maintained through water uptake (Van Doorn and Reid, 1995) as compared to control. The observational data on useful and total vase life of foliages as affected by different stages had been presented in Table 3, showed significant influence of $0.75 \%$ (i.e. 11 and 12 days) wax emulsion treatment on vase life of Eucalyptus foliages. This might be due to the artificial application of wax on the surface of leaves reduces the opening and closing mechanism of stomata, which results in lower respiration and transpiration. The results obtained were in close conformity with the findings of Jones and Sedgley (1993) who revealed that all species of Eucalyptus have rod shaped waxes on the foliage, except Eucalyptus baueriana, which affects longevity. In an another experiment by Wirthensohn and Sedgley (1996) showed that changes in wax morphology of juvenile foliage with leaf age of 18 species of Eucalyptus species had tube wax on juvenile leaves but there were differences between the species in the length and conformation of tubes and percentage surface covered by wax.

\section{Conclusion}

The use of wax emulsions improved the quality and increased vase life of different ornamental cut foliage. As from our study we found that various concentrations of wax emulsion gave improvement in post harvest quality in terms of weight, water uptake and increased cut foliage vase life of Asparagus ( $A$. densiflorus 'Sprengeri'), Heliconia (H. psittachroum cv. Golden Torch), Fishtail palm (Caryota urens) and Eucalyptus (E. teritecornis).

\section{ACKNOWLEDGEMENTS}

The authors are thankful to Dr B K Dhaduk whose guidance and support made the work successful. Also acknowledge the facilities and funding provided by ASPEE College of Horticulture and Forestry, Navsari Agricultural University, Navsari, Gujarat, India

\section{REFERENCES}

Bhattacharjee, S.K. (1999). Post-harvest management of cut flowers, cut foliage and post production of potted plants. J. Orn. Hort, New series, 2(1): 32-39.

CPIDC (2009). Market Survey: The EU market for foliage. Centre for promotion of imports from developing countries. pp. 1-20. Retrieved in June, 242009 from www.cbi.eu/system/files/marketintel/200920 20foliage1.pdf

Cutler, D.F., Alvin, K., L., and Price C.V. (1980). The plant cuticle. Academic press, Inc., New York.

Ferrante, A., Mensuali-Sodi, A., Serra, G. and Tognoni, F. (2000). La durata postraccolta di Eucalyptus parvifolia Cambage. Colture Protette, 7: 79-84.

Halevy, A.H., Kofranek, A.M. and Besemer, S.T. (1978). Postharvest handling methods for bird-of-paradise flowers (Sterlitzia reginae Ait). J. Amer. Soc. Hort. Sci.,103:165-169.

Halevy, A.H. (1995). The use of plant bio-regulators in ornamental crops. Acta Hort.,394: 37-43.

Jayshienge, W., A., C., T. and Peiris, S., E. (2009). Investigation of use of locally available oils and waxes to prolong the vase-life of Phoenix roebelenii a cut foliage. Proceedings of National Symposium on Floriculture Research. pp 53-60

Jones, M. and Sedgley, M. (1993). Leaf waxes and post harvest quality of eucalyptus foliages. J. Hort. Sci., 68 (6): 939-946.

Mujaffar, S. and Sankat, C.K. (2003). Effect of waxing on the water balance and keeping qualities of cut Anthuriums. International Agrophysics, 17 (2): 77-84.

Narayana, C.K., Pal, R.K. and Roy, S.K. (1996). Effect of pre-storage treatments and temperature regimes on shelf life and respiratory behaviour of ripe Baneshan mango. $J$. Food Sci. Tech., 33(1): 79-82.

Nowak, J. and Rudnicki, R.M. (1990). Postharvest handling and storage of cut flowers, florist greens and potted plants. Timber Press Inc., Portland, Oregon. pp 210-245.

Paul, R.E. and Goo, T.C.C. (1985). Ethylene and water stress in the senescence of cut Anthurium flowers. J. American Soc. Hort. Sci., 110 (1): 84-88.

Pritchard, M.K., Hew, C.S. and Wang, H. (1991). 
Low-temperature storage effects on sugar content, respiration and quality of Anthurium flowers. J. Hort. Sci.,66: 209-214.

United States Department of Agriculture. (2001). Floriculture crops 2000 Summary. USDA, Washington, DC.

Van Doorn, W.G. and Reid, M.S. (1995). Vascular occlusion in stems of cut rose flowers exposed to air: Role of xylem anatomy and rates of transpiration. Physiol. Plantarum., 93: 624-629.

Welch, C.K. and Cameron, A.C. (1990). Evaluated temperatures during stimulated marketing reduce field performance of packaged rose bushes. Hort. Sci.,25(6): 677-679.

Wirthensohn, M.G. and Sedgley, M. (1996). Epicuticular wax structure and regeneration on developing juvenile Eucalyptus leaves. Australian J. Bot., 44(6): 691-704. 